\title{
En 66 år gammel kvinne med forvirring, afasi og myoklonier
}

\author{
En kvinne ble innlagt etter få ukers sykehistorie med episodiske nevrologiske symptomer. \\ Hun hadde ved innleggelse afasi, ataksi og myoklonier, men CT caput og rutineblodprøver \\ var normale. I en slik situasjon er en rekke differensialdiagoser aktuelle.
}

Se kommentar side 1043 og kunnskapsprøve på www.tidsskriftet.no/quiz

\author{
Line Broch \\ line.broch@sb-hf.no \\ Karl-Friedrich Amthor \\ Nevrologisk avdeling \\ Sykehuset Buskerud \\ 3004 Drammen
}

Pasienten er en 66 år gammel kvinne, som tidligere stort sett har vært frisk. Hun har $i$ en årrekke hatt svingende stoffskifteverdier. Ca. ett år før de aktuelle symptomene oppsto, fikk hun påvist behandlingstrengende hypotyreose. Ved en misforståelse ble planlagt substitusjonsbehandling igangsatt først ca. ti måneder senere. Ved senere kontroll hadde pasienten normale stoffskiftemarkører. Pasienten ble innlagt ved Nevrologisk avdeling ved lokalsykehuset med spørsmål om cerebralt insult pga. akutt innsettende afasi, kraftsvikt og ustøhet.

Ved innleggelse var pasienten motorisk urolig og forvirret, men for øvrig i god allmenntilstand. Hun kunne ikke gi adekvate anamnestiske opplysninger. Ifølge pårørende hadde pasienten $i$ perioder de siste ukene forut for innleggelsen vært mentalt endret, med episodisk forvirring, talevansker, ustøhet og skjelvinger. Ved klinisk undersøkelse frembød pasienten moderat afasi, ataksi og spredte myoklonier, men ingen øvrige fokale nevrologiske utfall. Cerebral CT ved innkomst viste beskjedne aldersdegenerative forandringer, ingen tegn til ferskt infarkt, blødning eller ekspansiv prosess. Røntgen thorax var negativt. Rutinemessige blodprøver, inkludert thyreoideastimulerende hormon (TSH) og fritt $T_{4}$, vitamin $B_{12}$ og folsyre var normale. Elektroencefalogrammet (EEG) viste patologiske forhold, med generelt langsom aktivitet uten fokalitet, epileptiform aktivitet eller trifasiske potensialer (fig 1).

Fravær av fokalnevrologiske utfall og normal cerebral CT talte imot innleggelsesdiagnosen cerebralt insult. Ved ovennevnte kliniske symptomer og EEG-forandringer er det naturlig å vurdere metabolsk encefalopati, eventuelt infeksiøse eller inflammatoriske tilstander som viral encefalitt, akutt demyeliniserende encefalomyelitt, progredierende multifokal leukoencefalopati, paraneoplastisk encefalitt eller cerebral vaskulitt som diagnoser. Nevrodegenerative lidelser som Alzheimers demens, demens med lewylegemer og Creutzfeldt-Jakobs sykdom kan debutere akutt og gi liknende symptomer. Intoksikasjon, delirium eller psykiatrisk sykdom er andre aktuelle differensialdiagnoser.

Det ble gjennomført spinalpunksjon, som viste blodtilblandet spinalvæske pga. innstikksblødning, lett pleocytose med hvite blodceller $5 \cdot 10^{6} /$, normal glukoseverdi og betydelig forhøyet proteinnivå i spinalvæsken 1,6 g/l. Cerebral MR avdekket beskjedne forandringer forenlig med kronisk iskemi, vurdert som normalt for pasientens alder. Det var normale funn ved tripleksundersøkelse av precerebrale arterier.

Spinalvæske og EEG-funn ble vurdert ikke å være typiske for infeksiøs encefalitt. EEG-forandringer med generell langsom aktivitet er uspesifikke og kan bl. a. ses ved metabolske encefalopatier eller intoksikasjon. Blodprøveresultatene ga imidlertid ingen holdepunkter for dette. Blodsukkerverdier, lever- og nyrefunksjonsprøver var normale. Det var ingen holdepunkter for overforbruk av alkohol eller for intoksikasjon med medikamenter.

De påfølgende to dager hadde pasienten fluktuerende nevropsykiatriske symptomer og korte perioder hvor hun virket relativt adekvat. Deretter tilkom en akutt forverring med økende motorisk uro, ataksi, forvirring og paranoide forestillinger. Det ble derfor foretatt ny spinalpunksjon som viste stigende blodcelletall til $11 \cdot 10^{6} / \mathrm{l}$ og konsentrasjon av spinalprotein til 3,3g/l, normal glukose. I påvente av svar på supplerende spinalvæskeundersøkelser ble det igangsatt behandling med Aciclovir $750 \mathrm{mg} \times 3$ og Ceftriaxon $2 \mathrm{~g}$ daglig. Ny MR caput var uendret med beskjedne kroniske iskemiske forandringer. Det ble gjort enfotonstomografi (single photon emission computed tomography, SPECT) av hjernen, men resultatet av undersøkelsen var vanskelig å tolke med henblikk på pasientens symptomer og bidro ikke til diagnostisk avklaring. Innkomne blodprøveresultater viste negativ antinukleært antistoff (ANA), revmatoid faktor immunoglobulin M (RF-igM) og RF-lgA.

Pga. klinisk forverring og stigende celletall i spinalvæsken vurderte vi encefalitt som den mest nærliggende diagnosen, selv om celletallet var lavere enn forventet. Negative revmafaktorer og MR-funn talte mot vaskulitt.

De påfølgende dager skjedde det ingen endring i pasientens tilstand. Hun hadde ingen åpenbar effekt av antiviral og antibakteriell behandling. Nå foreliggende prøvesvar viste negativt svar for thyreoideareseptorantistoff (TRAS), men sterkt forhøyet anti-thyreoideaperoksidase (TPO) > 2000 enheter. Serumundersøkelser med henblikk på Epstein-Barr-virus, cytomegalovirus, Borrelia burgdorferi og lues var negative. Herpes simplex-polymerasekjedereaksjon, Borrelia IgM-antistoff, lues og dyrking av bakterier i spinalvæsken var negativ. Vi valgte derfor å seponere behandlingen med Aciclovir og Ceftriaxon.

Med kjent hypotyreose, tilstedeværelse av anti-TPO-antistoffer og fravær av annen årsak til encefalopati, diagnostiserte vi sannsynlig Hashimotos encefalopati.

Det ble initiert peroral behandling med prednisolon $60 \mathrm{mg}$ daglig med frapperende effekt. Allerede etter noen dagers behandling var pasienten nærmest $i$ sin vanlige tilstand. Kontroll-EEG viste normal kurve (fig 2). Prednisolonbehandling pågikk i nedtrappende dosering over tre måneder. Ny spinalpunksjon viste normalisering av verdiene for spinalprotein. Undersøkelsesresultatene for demensmarkører og protein 14-3-3 i spinalvæsken med tanke på Creutzfeldt- 


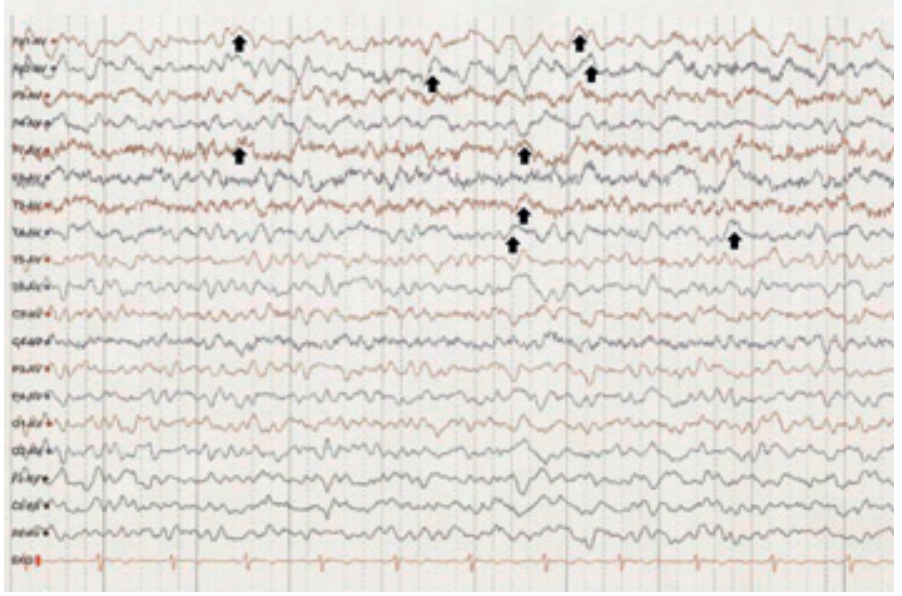

Figur 1 EEG-registrering før oppstart av behandling med steroider er patologisk og viser et uryddig og uregelmessig kurvebilde med overvekt av langsomme bølger (2-3 Hz) i frontotemporale avledninger (piler) på både høyre (blått) og venstre (rødt) side

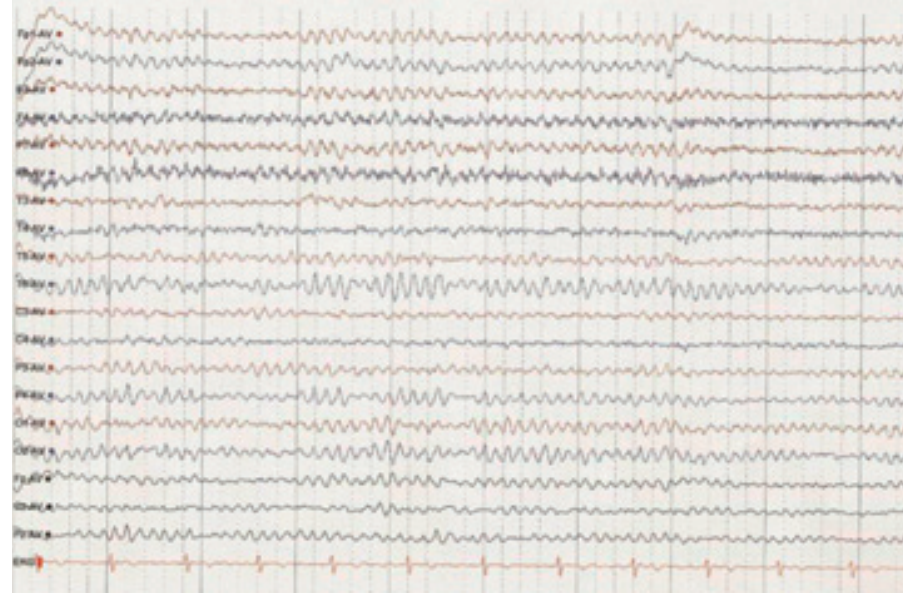

Figur 2 EEG-registrering ca. seks uker etter oppstart med steroidbehandling viser normalisering av kurvebildet med en regelmessig, rytmisk hjerneaktivitet på $8 \mathrm{~Hz}$ (alfarytme)
Jakobs sykdom forelå først noen uker etter utskrivning. Resultatet for demensmarkører var negativt, for protein 14-3-3 positivt. Betydningen av funnet ble vurdert som usikker, muligens var resultatet falskt positivt pga. blodtilblanding. Sykdomsforløpet utelukket Creutzfeldt-Jakobs sykdom.

Ved senere polikliniske kontroller, sist 16 måneder etter seponering av prednisolon, var pasienten fortsatt symptomfri og uten tegn til residiv.

\section{Diskusjon}

Encefalopati assosiert med autoimmun tyreoiditt og hypotyreose ble første gang beskrevet i 1966 av Brain og medarbeidere (1). Syndromet fikk etter hvert betegnelsen Hashimotos encefalopati (HE). Fordi de fleste pasienter responderer på behandling med steroider, betegnes tilstanden også som steroid responsiv encefalopati assosiert med autoimmun tyreoiditt (SREAT) (2). Tilstanden debuterer som en akutt eller subakutt innsettende, ofte noe fluktuerende encefalopati. Basert på klinisk presentasjon skilles det mellom to, ofte overlappende subtyper. En anfallsvis (relapsing/remitting) type eller vaskulittype debuterer med slagliknende episoder og encefalopati med varierende kognitiv svekkelse. En noe sjeldnere forekommende diffus, progredierende type har snikende debut, innebærer økende svekkelse av mentale funksjoner og etter hvert utvikling av demens, forvirring, psykose, somnolens eller koma (3). Andre ledsagende symptomer er epileptiske anfall, hjerneslagliknende episoder, myoklonier, tremor, ataksi, hodepine, gangvansker og psykiatriske symptomer (3, 4). Hyppigst forekommer fokale eller generaliserte tonisk-kloniske kramper. Dette ses hos om lag to tredeler av pasientene (4).

Hashimotos encefalopati er en sjelden tilstand. En oversiktsartikkel publisert i 2006 identifiserte kun 121 publiserte tilfeller hos voksne (5). En sykehusbasert, epidemiolo- gisk studie estimerte en prevalens på 2,1 per 100 000. Kvinner affiseres oftere enn menn, med en ratio på ca. $4: 1$. Median alder ved debut angis til 46 år (5). Hashimotos encefalopati bør overveies som en aktuell diagnose ved samtidig forekomst av encefalopatisymptomer og autoimmun thyreoideasykdom. Mistanken styrkes ved påvisning av økte anti-thyreoideaantistoffer, spesielt anti-TPO, og patologiske funn ved EEG og i spinalvæsken. Diagnosen støttes ytterligere ved steroidrespons.

Thyreoideastatus viser stor variasjon fra subklinisk hypotyreose (hyppigst), manifest hypotyreose, eutyreose til hypertyreose (sjeldent) $(2,4)$.

Forhøyede serumverdier av TgAb anti-tyroglobulinantistoff $\mathrm{TgAb}$ påvises hos ca. $70 \%$ og anti-TPO, den viktigste diagnostiske markør for å stille diagnosen, hos $95-100 \%$ av pasientene $(2,4)$. Antistoffene har sannsynligvis ingen patogenetisk betydning. Det finnes ingen sammenheng mellom den kliniske alvorlighetsgraden av encefalopati og serumkonsentrasjonen av antistoff $(2,3)$. Det ses heller ingen sikker endring i serumkonsentrasjonen ved behandling. Anti-thyroideaantistoffer påvises hos $2-20 \%$ friske personer og er ikke spesifikke for Hashimotos encefalopati. Anti-TPO kan også påvises hos pasienter med annen autoimmun sykdom, som systemisk lupus erythematosus (SLE).

Patologiske funn i spinalvæsken avdekkes hos ca. $85 \%$ av pasientene. Forhøyet konsentrasjon av spinalprotein forekommer i ca. $75 \%$ av tilfellene (2). Glukosenivået er angitt alltid å være normalt (3). Uspesifikke EEG-forandringer ses hos 90-98\% (5), hyppigst i form av moderat til markert, uspesifikk, langsom bakgrunnsaktivitet. MR og CT kan vise uspesifikke høysignalforandringer i subkortikal hvit substans, men er som regel normale (5)

Symptomer og funn ved Hashimotos en- cefalopati viser betydelig grad av variasjon. Det kliniske bildet kan imitere en rekke vanligere tilstander, og diagnosen kan derfor være vanskelig å stille. En studie fra Mayoklinikken, der man gjennomgikk 20 pasienter med Hashimotos encefalopati diagnostisert i tidsrommet 1995-2003, fant man at samtlige pasienter initialt var feildiagnostisert (2), hyppigst med viral encefalitt, dernest Creutzfeldt-Jakobs sykdom, cerebrovaskulær sykdom eller degenerativ demens. Diagnosen stilles vanligvis etter at vanligere årsaker til encefalopati er utelukket.

Patofysiologien ved Hashimotos encefalopati er fortsatt uklar. Autoimmune mekanismer antas å være av vesentlig etiologisk betydning. Antakelsen støttes av at syndromet er assosiert med andre autoimmune sykdommer, økt forekomst hos kvinner, inflammatoriske forandringer i spinalvæsken og steroidrespons (3). Cerebral vaskulitt som følge av immunkompleksnedslag er blitt foreslått som en mulig patogenetisk mekanisme $(3,6)$.

Behandling med kortikosteroider er førstevalg og kan gi rask og komplett remisjon. Peroral administrasjon av prednisolon, 60-150 mg daglig i 10-30 dager med gradvis nedtrappende dose over flere måneder er effektivt (3). Alternativt kan det gis intravenøs metylprednisolon $1 \mathrm{~g}$ i fem dager, etterfulgt av peroral vedlikeholdsdose (7). Anbefalt behandlingsvarighet angis fra 3-6 måneder til ett år. Dosering og varighet av behandling er fortsatt gjenstand for diskusjon. Effekt av langtidsbehandling er ikke kjent. Oppblussing av symptomene og tilbakefall under nedtrapping eller etter seponering av steroidbehandlingen er ikke uvanlig. Pasienter som utvikler residiv pleier påny å respondere på steroider. Det er ikke sett noen klar sammenheng mellom symptomvarighet før behandlingstart og behandlingsrespons. Mulig kan irreversibel hjerneskade forekomme i tilfeller med alvorlige sympto- 
mer av flere års varighet. Behandling med thyreoideahormon anbefales hos pasienter med påvist hypotyreose. Bedring av symptomene synes imidlertid ikke å være korrelert til substitusjonsbehandling (2).

Det er beskrevet effekt av intravenøs immunglobulinbehandling hos pasienter som ikke responderer på steroider (8). Plasmaferese er rapportert å ha effekt hos pasienter som ikke tolererer steroidbehandling (9).

\section{Konklusjon}

Hashimotos encefalopati er et sjeldent syndrom. Det er viktig å stille riktig diagnose og starte behandling tidlig fordi prognosen ved korrekt behandling er god.

Pasienten har gitt samtykke til at artikkelen blir publisert.
Oppgitte interessekonflikter: Ingen

\section{Litteratur}

Brain L, Jellinek EH, Ball K. Hashimoto's disease and encephalopathy. Lancet 1966; 2: 512-4.

2. Castillo P, Woodruff B, Caselli R et al. Steroidresponsive encephalopathy associated with thyroditis. Arch Neurol 2006: 63: 197-202.

3. Kothbauer-Margreiter I, Sturzenegger M, Komor $J$ et al. Encephalopathy associated with Hashimoto thyroiditis: diagnosis and treatment. J Neurol 1996; 243: 585-93.

4. Tamagno G. Federspil G. Murialdo G. Clinical and diagnostic aspects of encephalopathy associated with autoimmune thyroid disease lor Hashimoto's encephalopathy). Intern Emerg Med 2006; 1: 15-23.

5. Ferraci F, Carnevale A. The neurological disorder associated with thyroid autoimmunity. J Neurol 2006; 253: 975-84

6. Forchetti CM, Katsamakis G, Garron DC. Autoimmune thyroiditis and a rapidly progressive dementia: global hypoperfusion on SPECT scanning suggests a possible mechanism. Neurology 1997; 49 ; $623-6$
7. Rodriguez AJ, Jicha GA Steeves TDL et al. EEG changes in a patient with steroid-responsive encephalopathy associated with antibodies to thyroperoxydase (SREAT, Hashimoto's encephalopathyl. J Clin Neurofysiol 2006: 23: 371-3.

8. Jacob S, Rajabally YA. Hashimoto's encephalopathy: steroid resistance and response to intravenous immunoglobulins. J Neurol Neurosurg Psychiatry 2005; 76: 455-6.

9. Nieuwenhuis L, Santens P, Vanwalleghem P et al. Subacute Hashimoto's encephalopathy, treated with plasmapheresis. Acta Neurol Belg 2004; 104 $80-3$.

Manuskriptet ble mottatt 20.5. 2009 og godkjent 14.1. 2010. Medisinsk redaktør Trine B. Haugen.

\section{Kommentar}

\section{Autoimmun encefalopati}

Denne kasuistikken illustrerer diagnostiske utfordringer ved subakutt encefalopati. Ved akutt innsettende afasi, kraftsvikt og ustøhet var innleggelsesdiagnosen hjerneslag rimelig. Flere forhold pekte imidlertid $i$ en annen retning: Pasienten hadde hatt mental endring i ukene forut for innleggelsen, fokalnevrologiske utfall ble ikke påvist, og radiologisk diagnostikk viste verken blødning eller infarkt. Betydelig og økende innhold av protein og økt celletall i spinalvæsken pekte i retning av inflammatorisk sykdom. Encefalitt var derfor en nærliggende diagnose.

Hva så når vanlig mikrobiologisk diagnostikk ikke gir napp? Prøvesvarene kan være falskt negative, eller pasienten kan ha en annen infeksjon. Siden pasienten også hadde myoklonier, var Creutzfeldt-Jakobs sykdom en klar mulighet. Dersom pasienten kan ha immunsvikt, er det viktig å huske muligheten av at det kan foreligge opportunistiske infeksjoner, slik som progredierende multifokal leukoencefalopati.

Autoimmunitet, eller inflammasjon uten infeksjon, er en annen mulighet. Multippel sklerose og akutt demyeliniserende encefalomyelitt kan begge forårsake akutt encefalopati, men gir gjerne typiske MR-forandringer. Spinalvæskeundersøkelsen tydet heller ikke på multippel sklerose.

I de senere år har man fått økt kunnskap om autoimmun encefalopati assosiert med spesifikke autoantistoffer. Autoimmun en- cefalopati kan være reversibel ved korrekt behandling, og spesifikke autoatistoffer kan være nøkkelen til diagnosen (1). Paraneoplastisk encefalomyelitt og limbisk encefalitt assosiert med autoantistoffer mot onkonevrale antigener som $\mathrm{Yo}, \mathrm{Hu}$ og CV2, er kjente eksempler (2). Imidlertid har ikke alle pasienter med autoimmun encefalopati underliggende malignitet, og ved dramatiske sykdomsbilder kan kortikosteroider gi effekt. Dette gjelder særlig pasienter med antistoffer rettet mot proteiner som er uttrykt på overoverflaten av nevroner, slik som $\mathrm{N}$ metyl-D-aspartatreseptorer (NMDA), spenningsavhengige kaliumkanaler (VGKC) og $\mathrm{GABA}_{\mathrm{B}}$-reseptorer (3). Således ble det nylig rapportert at 15 pasienter som hadde fått diagnostisert Creutzfeldt-Jakobs sykdom på klinisk grunnlag, viste seg å ha autoimmun encefalopati med anti-VGKC-antistoffer (4). Kun tredjeparten hadde påvisbar tumor, mens 12 av 13 som fikk immunsuppressiv behandling ble bedre - hos fem ble effekten beskrevet som dramatisk.

Pasienter med autoimmun encefalopati kan ha flere autoantistoffer og også annen autoimmun sykdom, ikke sjelden tyreoiditt. Ved autoimmun encefalitt med anti-GA$\mathrm{BA}_{\mathrm{B}}$-reseptorantistoffer hadde halvparten av pasientene også antistoffer mot TPO, GAD65, eller spenningsavhengige kalsiumkanaler (5). Forekomst av nevronantistoffer er ikke blitt systematisk undersøkt ved Hashimotos encefalopati. Det er mulig at pasientene i tillegg til anti-TPO også har nevronantistoffer som er viktigere i patogenesen, og at tilstanden ikke er en egen entitet (5). For klinikeren er imidlertid hovedbudskapet at akutt encefalopati kan skyldes autoimmunitet og respondere på immunsuppresjon, og at analyse av nevron- og thyreoideaantistoffer kan bidra til diagnosen.

\section{Trygve Holmøy}

trygve.holmoy@rr-research.no

Nevrologisk avdeling

Oslo universitetssykehus, Ullevål

Oppgitte interessekonflikter: Ingen

\section{Litteratur}

1. Darnell R, Poser JB. Autoimmune encephalopathy: the spectrum widens. Ann Neurol 2009; 66 $1-2$

2. Storstein A, Vedeler CA. Paraneoplastiske nevrologiske syndromer. Tidsskr Nor Legeforen 2009: 129: $524-8$

3. Graus F, Saiz A, Dalamau J. Antbodies and neuro nal autoimmune disorders of the CNS. J Neurol 2009: 257: 509-17.

4. Geschwind MD, Tan KM, Lennon VA et al. Voltagegated potassium chanels autimmunity mimicking Creutzfeldt-Jakob disease. Arch Neurol 2008; 65: 1341-6.

5. Lancaster E, Lai M, Hughes E et al. Antibodies to the $G_{A B A}$ receptor in limbic encephalis with seiz ures: case series and characterisation of the antigen. Lancet Neurol 2010; 10: 67-76.

Manuskriptet ble mottatt 11.3. 2010 og godkjent 8.4. 2010. Medisinsk redaktør Trine B. Haugen. 